Bangladesh J. Bot. 43(1): 91-95, 2014 (June)

\title{
TRICHOME MORPHOLOGY OF AJUGA ORIENTALIS L. (LAMIACEAE) FROM TURKEY
}

\author{
Ilkay ÖZtürk Çali*, Arzu Cansaran ${ }^{1}$ and Cengiz Yildirim ${ }^{1}$ \\ Department of Biology, Art and Science Faculty, Amasya University, Amasya,Turkey
}

Key words: Ajuga orientalis, Trichome morphology

\begin{abstract}
Absract
Morphology and localization of the trichomes on vegetative and reproductive organs of Ajuga orientalis L. from Turkey were investigated. Peltate, capitate glandular and non-glandular trichomes were found on the stem, leaf, petiole, calyx and corolla surfaces of A. orientalis. Three sub-types of capitate glandular trichomes were found whereas two sub-types of non-glandular ones were stated on the several organs of A. orientalis. Glandular trichomes were mainly observed on calyx and corolla, but non-glandular ones were found on the stem, leaf surface and petiole.
\end{abstract}

\section{Introduction}

Lamiaceae is a large family and represented by 200 genera and about 3200 species globally (Tavukçuoğlu et al. 1996). This family shows natural distribution having approximately 45 genera and about 546 species in Turkey (Davis 1982). The species of the genus Ajuga L. of the family are evergreen, clump-forming rhizomatous annual or perennial herbaceous flowering plants. It comprises about 90 species, mostly distributed in the north temperate zone of the world. These plants, growing in Europe, Asia, Africa, Australia and North America and are used in gardens as ground cover or border for their foliage and beautiful flowers. In Turkey, Ajuga is represented by 14 species and 27 subspesific taxa (Davis 1982, Baytop 1999). Some species of Ajuga have been widely used for their aromatic, diuretic, antipyretic, tonic, diaphoretic, astringent, bitter and homeopathic properties in the Turkish folk medicine (Baytop 1999).

The taxonomic significance of trichome structure is well known in lamiaceae and related families (Metcalfe and Chalk 1972). There is no study on trichome morphology of Turkish Ajuga orientalis L. and its taxonomic value. The purpose of this study was to determine the morphology and localization of glandular and non-glandular trichomes on vegetative and reproductive organs of $A$. orientalis. It was also aimed to state the taxonomic value of trichomes in this species.

\section{Materials and Methods}

The plant specimens of Ajuga orientalis L. were collected from the natural populations in Amasya (in the vicinity of Direkli village, June 2012, İÖztürk Çal1 461) which is a city in the Black Sea region of Turkey.

Trichome morphological investigations were performed using fresh specimens preserved in $70 \%$ alcohol. Trichomes were obtained from stem, leaf blade, petiole, calyx, corolla by transverse and surface sections. The sections were made by hand using commercial razor blades. They were studied with a Leica ICC50 HD binocular light microscope by using a Leica Digital Camera. The types and distributions of trichomes are described. The general trichome terminology follows Metcalfe and Chalk (1972), Payne (1978) and Navarro and El Oualidi (2000).

*Author for correspondence: <ilkaycali@hotmail.com>. 


\section{Results and Discussion}

Three different types of trichome were recorded on the vegetative and reproductive organs of A. orientalis. These are peltate, capitate glandular and non-glandular (Figs 1-12). It was also determined that reproductive organs have numerous glandular trichomes whereas vegetative organs possess many non-glandular trichomes. Besides, three subtypes of capitate glandular and two subtypes of non-glandular trichomes were found on five types of vegetative and reproductive organs. Data of the trichome types observed and their localization are given in Table 1.

Table 1. Types of trichome and their localization in Ajuga orientalis.

\begin{tabular}{|c|c|c|c|c|c|c|c|c|c|c|c|c|c|c|}
\hline \multirow{3}{*}{$\begin{array}{l}\text { Plant } \\
\text { organ }\end{array}$} & \multirow{3}{*}{$\frac{\text { Peltate }}{\text { Type I }}$} & \multicolumn{11}{|c|}{ Capitate } & \multicolumn{2}{|c|}{ Non-glandular } \\
\hline & & \multicolumn{4}{|c|}{$\begin{array}{c}\text { Type IIA } \\
\text { Stalk 1-4 cells }\end{array}$} & \multicolumn{4}{|c|}{$\begin{array}{c}\text { Type IIB } \\
\text { Stalk 1- } 5 \text { cells }\end{array}$} & \multicolumn{3}{|c|}{$\begin{array}{l}\text { Type IIC } \\
\text { Stalk 1- cells }\end{array}$} & \multirow[t]{2}{*}{$\begin{array}{l}\text { Type } \\
\text { IIIA }\end{array}$} & \multirow{2}{*}{$\begin{array}{l}\text { Type } \\
\text { IIIB }\end{array}$} \\
\hline & & 1 & 2 & 3 & 4 & 1 & 2 & 3 & 4 & 5 & 1 & 2 & & \\
\hline Stem & + & + & - & - & + & + & - & - & + & + & - & - & +++ & - \\
\hline $\begin{array}{l}\text { Adaxial } \\
\text { surface } \\
\text { of leaf }\end{array}$ & ++ & + & - & - & - & - & - & - & - & - & - & - & +++ & + \\
\hline $\begin{array}{l}\text { Abaxial } \\
\text { surface } \\
\text { of leaf }\end{array}$ & +++ & + & - & + & ++ & + & + & + & + & + & - & - & +++ & +++ \\
\hline Petiole & + & + & + & - & - & - & - & - & - & - & - & - & +++ & + \\
\hline Calyx & +++ & +++ & ++ & ++ & - & +++ & ++ & + & + & - & ++ & + & ++ & + \\
\hline Corolla & ++ & +++ & +++ & +++ & - & +++ & +++ & +++ & ++ & + & +++ & + & ++ & + \\
\hline
\end{tabular}

Type I. Peltate trichomes. Type II. Capitate trichomes consisting of three types IIA, IIB and IIC). Type III. Non-glandular trichomes consisting of two types. (-) shows absence of trichomes, (+) shows a few trichomes, $(++,+++)$ show a lot of trichomes.

Glandular trichomes consists of three types. Type I is the typical peltate glandular trichome. This trichomes have a basal cell, a monocellular stalk cell and a large multicellular secretory head composed of central cells and peripheral cells. Multicellular secretory head has one or four secretory cells, four or eight peripheral cells ranged in a circle around it. The anticlinal wall of the stalk cell was cutinized (Figs 1-2). Materials are secreted from the head cells through their outer wall into a space elevation of their common cuticle together with an outer layer of the cell wall. Peltate trichomes on the organs of the members of the family Lamiaceae, frequently have multicellular secretory head cells (up to sixteen) a monocellular stalk and a basal epidermal cell (Hallahan 2000, Kamatou et al. 2006). In the present study, it was found that A. orientalis has peltate trichomes consisting of a four or twelve celled head in a single circle. The findings of the present study are consistent with previous studies (Corsi and Bottega 1999, Hallahan 2000, Kamatou et al. 2006, 2007).

In the study, it was also determined that peltate trichomes were found abundantly on the corolla, leaf surfaces and calyx whereas the same trichomes were rare on the stem and petiole of this plant (Table 1). These findings are the similar with previous studies (Corsi and Bottega 1999, Serrato-Valenti et al. 1997)

Glandular trichomes of Type II are capitate and each composed of a basal epidermal cell, unicellular to multicellular stalk cell, a neck cell and a large, cutinized, unicellular or bicellular secretory head (Figs 3-8). The capitate hairs, vary greatly in structure, size, proportions, occurence on plant organs and manner of secretion. Capitate glandular trichomes can be subdivided into three subtypes. Subtype IIA: A unicellular or bicellular head and a stalk of one to four cells (Figs 3-5). Subtype IIB: A cup-shaped unicellular head and one to five-celled stalk (Figs 6-7). 

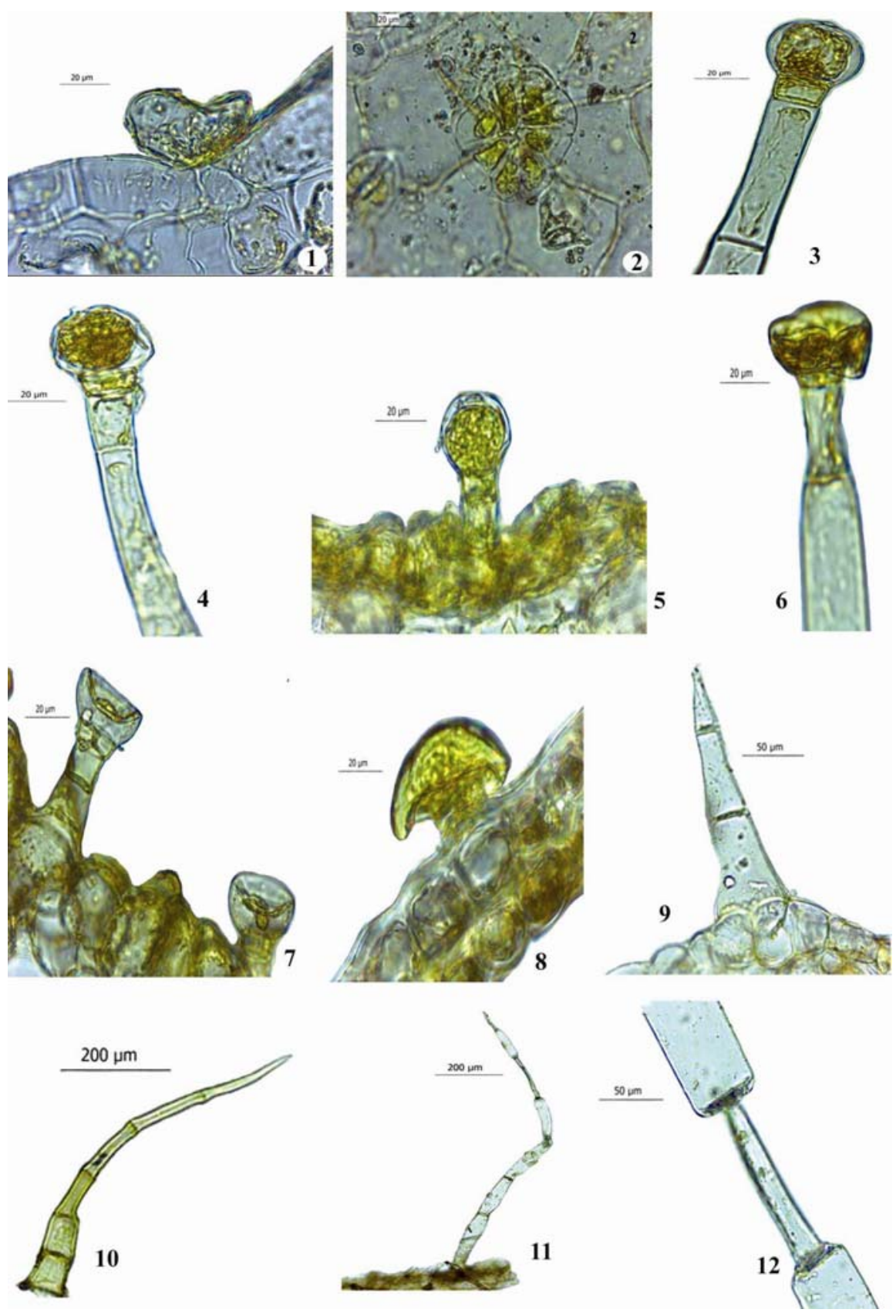

Figs 1-12: Differential types of trichome grew on Ajuga orientalis. 1 - 2. Type I peltate glandular trichomes of Ajuga orientalis on the leaf abaxial surface (1), the leaf adaxial surface (2). 3 - 8. Type II capitate glandular trichomes of Ajuga orientalis. Type IIA on the stem (3), Type IIA on the corolla (4), Type IIA on the calyx (5), Type IIB on the stem(6), Type IIB on the calyx (7), Type IIC on the stem (8). $9-12$. Type III non glandular trichomes of Ajuga orientalis. Type IIIA on the leaf (9), Type IIIA on the stem (10), Type IIIB on the leaf (11), Type IIIB on the leaf (12). 
Sub-type IIC: A hemispherical unicellular head and a unicellular or bicellular stalk (Fig. 8). According to Navarro and El Oualidi (2000), capitate glandular trichomes are a significant taxonomic character of the Lamiaceae family. The morphology, distribution and frequency of glandular trichomes are used as taxonomic characters at subfamily level in the Lamiaceae (Ascensao et al. 1995). In the present study, the capitate trichomes were frequently observed in A. orientalis especially on the reproductive organs of this plant. It was reported that the capitate trichomes types were found widely in many species of Lamiaceae (Serrato-Valenti et al. 1997, Werker et al. 1985, Bisio et al. 1999). However, they greatly vary in structure and size. The findings of the present study are consistent with those of the literature. In the present investigation, all of the capitate sub-type trichomes (IIA, IIB and IIC) were recorded.

Type III trichome is also a non-glandular trichome as well. This type has one basal epidermal cell. It can be unicellular or multicellular, rarely branched (Figs 9 - 12). They are two subtypes, namely, IIIA and IIIB. Sub-type IIIA is a unicellular or multicellular acicular trichome (Figs 9 10). This subtype was commonly observed to grow on vegetative organs of A. orientalis. Especially long multisellular subtype IIIA trichomes were commonly determined on the abaxial surfaces of the A. orientalis leaf. It was rarely observed as curved. Subtype IIIB is a kind of special trichome. It is a multicellular, with ridges (Figs $11-12$ ) and is very common on the abaxial surface of the leaf. This subtype IIIB, as observed in A. orientalis, is different from those determined in Salvia (Corsi and Bottega 1999, Siebert 2004, Kamatou et al. 2007).

In conclusion, the glandular and non-glandular trichomes on the vegetative and reproductive organs of A. orientalis are similar to the glandular and non-glandular trichomes of other members of Lamiaceae family. However, some important differences can be determined in the morphology and localization of the trichomes of this species.

\section{References}

Ascensao L, Marques N and Pais MS 1995. Glandular trichomes on vegetative and reproductive organs of Leonotis leonurus (Lamiaceae). Ann. Bot 75: 619-626.

Baytop T 1999. Therapy with Medicinal Plants in Turkey, Past and Present. (2nd ed.) Nobel Tip Press. İstanbul, Turkey.

Bisio A, Corallo A, Gastaldo P, Romussi G, Ciarallo G, Fontana N, Tommasi N and Profumo P 1999. Glandular hairs and secreted material in Salvia blepharophylla Brandegee ex Epling grown in Italy. Ann. Bot. 83: 441-452.

Corsi G, Bottega S 1999. Glandular hairs of Salvia officinalis: new data on morphology, localization and histochemistry in relation to function. Ann. Bot. 84: 657-664.

Davis PH 1982. Flora of Turkey and the Aegean Islands. Vol. 7. Edinburgh Univ. Press. Edinburg, UK.

Hallahan DL 2000. Monoterpenoid biosynthesis in glandular trichomes of Labiatae plants. In: Advances in botanical research: Plant trichomes, Hallahan DL and Gray JC (Eds.), Academic Press, pp. 77-120.

Kamatou GPP, Van Zyl RL, Van Vuuren SF, Viljoen AM, Figueiredo AC, Barroso JG, Pedro LG and Tilney PM 2006. Chemical composition, leaf trichome types and biological activities of the essential oils of four related Salvia species indigenous to southern Africa. J. Essent. Oil Res. 18: 72-79.

Kamatou GPP, Viljoen AM, Figueiredo AC, Tilney PM, Van Zyl RL, Barroso JG, Pedro LG and Van Vuuren SF 2007. Trichomes, essential oil composition and biological activities of Salvia albicaulis Benth. and S. dolomitica Codd, two species from the Cape region of South Africa. S. Afr. J. Bot. 73: 102-108.

Metcalfe CR and Chalk L 1972. Anatomy of the Dicotyledons. Vol. II. Oxford University Press, Oxford.

Navarro T and El Oualidi J 2000. Trichome morphology in Teucrium L. (Labiatae), a taxonomic review. Anales Jardin Botanico de Madrid 57: 277-297.

Payne WW 1978. A glossary of plant hair terminology. Brittonia 30: 239-255. 
Serrato-Valenti G, Bisio A, Cornara L and Ciarallo G 1997 Structural and histochemical investigation 11 of the glandular trichomes of Salvia aurea L. leaves and chemical analysis of the essential oil. Ann. Bot. 79: $329-336$.

Siebert DJ 2004. Localization of salvinorin A and related compounds in glandular trichomes of the psychoactive sage, Salvia divinorum. Ann. Bot. 93: 763-771.

Tavukçuoğlu S, Kaynak G. and Tuyji O. 1996. Uludağ'da Yayılışı olan Thymus L. Türleri Üzerinde Morfolojik ve Anatomik Araştırmalar. Turk. J. Bot. 20: 59-71.

Werker E, Ravid U and Putievsky E 1985. Structure of glandular hairs and identification of the main components of their secreted material in some species of the Labiatae. Israel J. Bot. 34: 3145.

(Manuscript received on 10 September, 2013; revised on 4 March, 2014) 